\title{
FIRE IN THE DRAGON
}




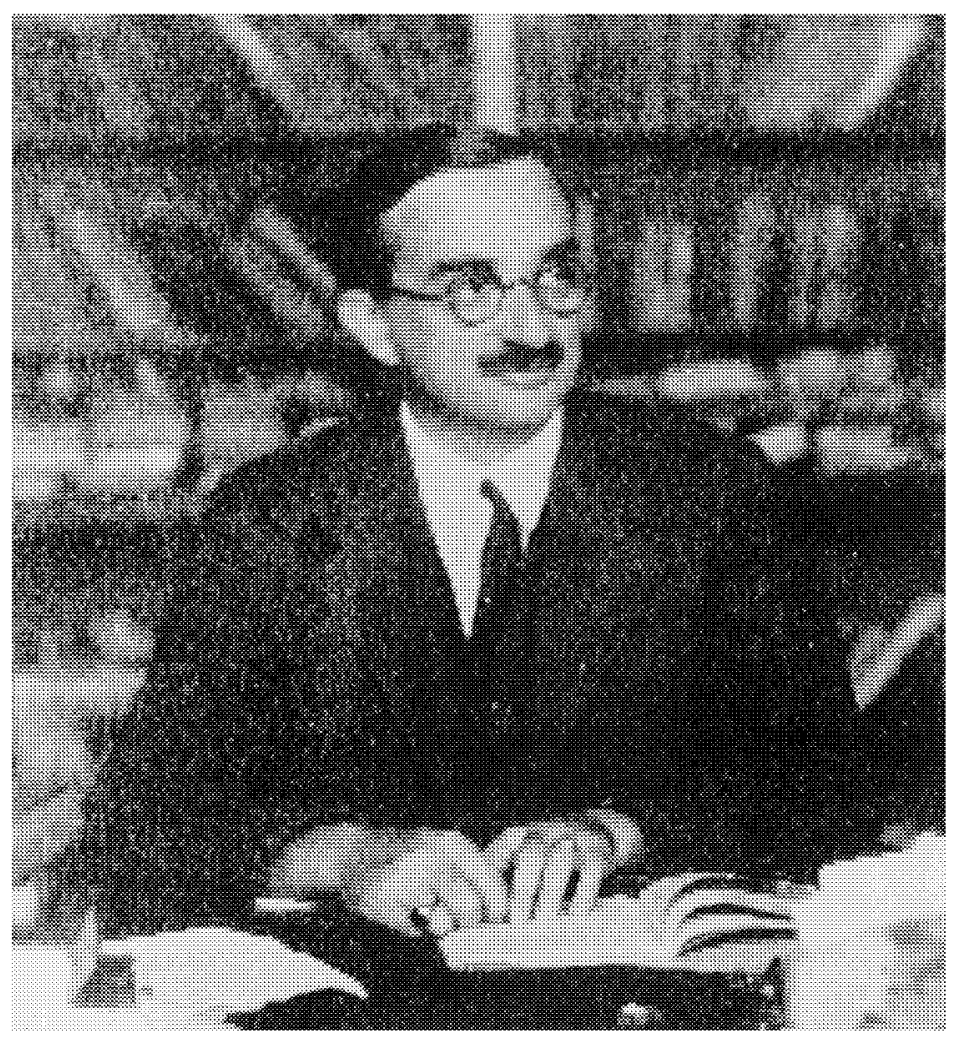

Géza Róheim, circa 1933; photograph courtesy of Dr. Werner Muensterberger. 


\title{
FIRE IN THE DRAGON
}

\author{
AND OTHER PSYCHOANALYTIC \\ ESSAYS ON FOLKLORE
}

Géza Róheim

Edited and Introduced by Alan Dundes

PRINCETON UNIVERSITY PRESS

PRINCETON, NEW JERSEY 
PUBLISHED BY PRINCETON UNIVERSITY PRESS, 41 WILLIAM STREET, PRINCETON, NEW JERSEY 08540

IN THE UNITED KINGDOM: PRINCETON UNIVERSITY PRESS, OXFORD COPYRIGHT $\odot 1992$ BY PRINCETON UNIVERSITY PRESS

ALL RIGHTS RESERVED

\section{LIBRARY OF CONGRESS CATALOGING-IN-PUBLICATION DATA}

ROHEIM, GÉZA, 1891-1953.

[ESSAYS. ENGLISH. SELECTIONS]

FIRE IN THE DRAGON AND OTHER PSYCHOANALYTIC ESSAYS ON FOLKLORE /

GÉZA RÓHEIM : EDITED AND INTRODUCED BY ALAN DUNDES.

$$
\text { P. CM.-(MYTHOS) }
$$

TRANSLATED FROM THE HUNGARIAN.

INCLUDES BIBLIOGRAPHICAL REFERENCES AND INDEX.

ISBN 0-691-09471-3 (CL)-ISBN 0-691-02868-0 (PB)

1. PSYCHOANALYSIS AND FOLKLORE. 2. FAIRY TALES-PSYCHOLOGICAL ASPECTS. 3. MYTHOLOGY-PSYCHOLOGICAL ASPECTS. I. DUNDES, ALAN.

II. TITLE. III. SERIES: MYTHOS (PRINCETON, N.J.)

GR42.R6413 $1992 \quad 398^{\prime} .019-$ dc20 91-36539

$\begin{array}{llllllllll}1 & 3 & 5 & 7 & 9 & 10 & 8 & 6 & 4 & 2\end{array}$

THIS BOOK HAS BEEN COMPOSED IN LINOTRON PALATINO

PRINCETON UNIVERSITY PRESS BOOKS ARE PRINTED ON ACID-FREE PAPER, AND MEET THE GUIDELINES FOR PERMANENCE AND DURABILITY OF THE COMMITTEE ON PRODUCTION GUIDELINES FOR BOOK LONGEVITY OF THE COUNCIL ON LIBRARY RESOURCES PRINTED IN THE UNITED STATES OF AMERICA 